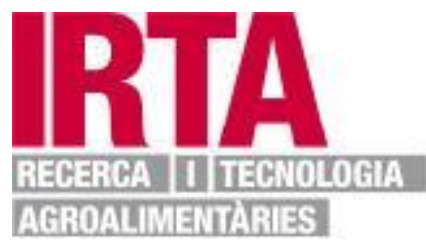

This document is a postprint version of an article published in Innovative Food Science and Emerging Technologies, copyright $\odot$ Elsevier B.V. after peer review.

To access the final edited and published work see:

http://dx.doi.org/10.1016/j.ifset.2011.01.011 


\title{
High pressure processing of swede (Brassica napus): Impact on quality properties
} Maria Clariana $^{\mathrm{a}}$, Juan Valverde ${ }^{\mathrm{b}}$, Hilde Wijngaard ${ }^{\mathrm{b}}$, Anne Maria Mullen $^{\mathrm{b}} *$ \& Begonya Marcos $^{\mathrm{b}}$

${ }^{a}$ IRTA-Food Technology, Finca Camps i Armet s/n, 17121 Monells, Spain

${ }^{\mathrm{b}}$ Teagasc, Ashtown Food Research Centre, Ashtown, Dublin 15, Ireland

* Corresponding author: anne.mullen@teagasc.ie

\begin{abstract}
The effects of combined pressure/ temperature treatments (200, 400 and $600 \mathrm{MPa}$, at 20 and $40{ }^{\circ} \mathrm{C}$ ) on the physical and nutritional properties of swede roots (Brassica napus var. napobrassica) were assessed. Changes induced by high pressure processing (HPP) on the original properties of swede samples were compared with those produced by thermal treatment (blanching). All studied treatments altered the physical properties of swede, resulting in a loss of hardness and water binding capacity. The strongest alteration of texture was observed after HPP at $400 \mathrm{MPa}$, while $600 \mathrm{MPa}$ was the treatment that better preserved the texture properties of swede. Blanching caused less total colour changes $(\Delta \mathrm{E})$ than HPP. Antioxidant properties of swede were measured as total antioxidant capacity, ascorbic acid and total phenol content. All treatments caused a loss of antioxidant capacity, which was less pronounced after HPP at $600 \mathrm{MPa}$ and 20 ${ }^{\circ} \mathrm{C}$ and blanching. Four glucosinolates were detected in swede roots, glucoraphanin, progoitrin, glucobrassicanapin and glucobrassicin. Glucobrassicanapin and glucobrassicin contents were reduced with all studied treatments. Progoitrin content was not affected by blanching and HPP at $200 \mathrm{MPa}$. HPP at higher pressure levels (400 and $600 \mathrm{MPa}$ ), though, induced an increase of progoitrin levels. The results indicated that blanching and HPP at $600 \mathrm{MPa}$ and $20^{\circ} \mathrm{C}$ were the treatments that better preserved the original quality properties of swede.
\end{abstract}

Keywords: High pressure processing; Swede; Texture; Antioxidants; Glucosinolates. 


\section{Introduction}

Over the last years there has been an increase in consumer demand for minimally processed foods, more similar to fresh products, without the presence of additives. At the same time and due to new consumption habits, there is an increase in consumption of ready to eat products. One of the main problems in manufacturing healthy ready to eat products, such as fresh-cut vegetables is their short shelf life. Therefore, extension of food shelf life using mild processing technologies that minimally affect the sensory and texture of the products is a challenge for the food industry.

Traditionally, foods of vegetable origin are submitted to a thermal treatment (water blanching) to reduce the microbial load and inactivate deleterious enzymes responsible of quality deterioration during storage (Cano, Hernandez, \& Ancos, 1997; Lee \& Coates, 1999). However, heat treatment has some detrimental effects on the texture, sensory and nutritional value of vegetables (Podsedek, 2007; Roy, Takenaka, Isobe, \& Tsushida, 2007). In the last years, the application of high pressure processing (HPP) on products of vegetable origin as an alternative to blanching processing to inactivate microorganisms and enzymes responsible of food deterioration with minimal alteration of quality has been extensible studied (Castro et al., 2008; Eshtiaghi \& Knorr, 1993; Hendrickx, Ludikhuyze, Van den Broeck, \& Weemaes, 1998). HPP mainly affects noncovalent bonds, allowing a better preservation of micronutrients such as hydrophilic vitamins, pigments and flavour (Oey, Van der Plancken, Van Loey, \& Hendrickx, 2008). The effects of HPP on the colour and texture is dependent on the type of vegetable (Oey, Lille, Loey, \& Hendrickx, 2008).

Swede (Brassica napus var. napobrassica) commonly known as rutabaga in America, and turnip in Ireland, is a vegetable from the Brassicaceae family (Grubben \& Denton, 2004). Early, small swedes can be shredded and served raw. Larger specimens can be cut into pieces and consumed in soups or as a side dish in the roast. Swede is known to have a high content of beneficial health compounds including phenolic compounds, glucosinolates and vitamin C (Paul \& Southgate, 1978; Podsedek, 2007). Some of these compounds can be lost during the thermal treatment, depending on the processing conditions (Podsedek, 2007; Roy et al., 2007). HPP has been assessed as a mild technology to process other vegetables from the Brassica family such as broccoli and cauliflower (Prestamo \& Arroyo, 1998; Van Loey et al., 1998). HPP have shown 
minimal effects on the pigments and antioxidant capacity (Oey, Van der Plancken, et al., 2008; Oey, Lille, et al., 2008). Moreover, HPP proved to provide beneficial health benefits by inducing hydrolysation of glucosinolates (Van Eylen et al., 2009). However, HPP can also have a detrimental impact on the quality of vegetables. Therefore, it is essential for consumer acceptance to assess the effects of HPP on the quality. The objective of the present study was to investigate the effect of combined pressure/temperature treatments on the texture, colour, antioxidant properties and glucosinolate profile taking as a reference a non-treated swede and swede processed with a traditional thermal treatment (blanching).

\section{Material and methods}

\subsection{Chemicals}

2, 2-Diphenyl-1-picrylhydrazyl (DPPH), 6-Hydroxy-2, 5, 7, 8- tetramethylchromane-2carboxylic acid (Trolox), pyrogallol, Folin-Ciocalteu reagent (2 N), sodium carbonate, gallic acid, tetradecylammonium bromide (TDAB), potassium phosphate monobasic $\left(\mathrm{KH}_{2} \mathrm{PO}_{4}\right)$, phosphoric acid $\left(\mathrm{H}_{3} \mathrm{PO}_{4}\right)$, L-ascorbic acid and silica gel were obtained from Sigma Aldrich (St. Louis, USA). Diatomaceous earth was obtained from Dionex (Idstein, Germany). Metaphosporic acid and solvents HPLC grade: methanol, acetonitrile and water were purchased from BDH Ltd. (Poole, UK).

\subsection{Sample preparation}

Swede roots (B. napus var. napobrassica) were purchased from a local Irish distributor. Inedible parts were removed with a sharp knife, obtaining a central cube that was further cut into two slices of approximately $15 \mathrm{~mm}$. Swede cylinders were obtained by punching each slice with a cork borer.

\subsection{High pressure processing (HPP) and thermal treatment}

Swede cylinders were double vacuum packed in $250 \mathrm{~g}$ portions into high oxygen barrier pouches (Versatile Packaging Ltd, Monaghan, Ireland). Packed samples were placed in a 1 litre high pressure unit with an internal size of $100 \mathrm{~mm}$ diameter $\times 254 \mathrm{~mm}$ height (Pressure Engineered System, Temse, Belgium). The pressurisation fluid was a mixture of water and rust inhibitor (Dowcal N, 60\% v/v). The samples were subjected to 
pressures of 200, 400 and $600 \mathrm{MPa}$ for $5 \mathrm{~min}$ at two temperature levels $20{ }^{\circ} \mathrm{C}$ and 40 ${ }^{\circ} \mathrm{C}$.

Swede samples for the thermal treatment (blanching) were placed in drilled bags to allow contact with hot water, and immersed in a water bath at $90{ }^{\circ} \mathrm{C}$ for $3 \mathrm{~min}$. After blanching, samples were immersed in cold water to promote rapid cooling. Each treatment was repeated three times. Non-treated (NT) samples were kept as control.

Physical measurements were performed on the same day of treatment. Samples for chemical analysis were frozen at $-20^{\circ} \mathrm{C}$ and subsequently freeze dried at $-50{ }^{\circ} \mathrm{C}$ and 0.03 mbar (Frozen in Time Ltd., York, UK). Lyophilised samples were vacuum packed and stored at $-80{ }^{\circ} \mathrm{C}$ until analysis. Three samples of each treatment were used for all analysis.

\subsection{Texture analysis}

Texture measurements were performed with a TAXT2i texture analyzer equipped with a $250 \mathrm{~N}$ cell (Stable Micro Systems, Surrey, England). Parameters for texture analysis were set according to Trejo-Araya et al. (2009) with some modifications.

A compression test was performed on swede cylinders of $14 \times 15 \mathrm{~mm}$ (diameter $\times$ length) placed in vertical position using a $20 \mathrm{~mm}$ perspex cylindrical probe. Hardness was measured as the peak force $(\mathrm{N})$ delivering $30 \%$ strain at a compression rate of 1 $\mathrm{mm} / \mathrm{s}$. A cutting test was performed on $14 \mathrm{~mm}$ diameter swede cylinders placed in horizontal position using a stainless steel blade. The test was performed at a penetration rate of $3 \mathrm{~mm} / \mathrm{s}$ and $75 \%$ strain. Results for cutting test were expressed as peak force $(\mathrm{N})$ and distance of displacement produced at maximum cutting force $(\mathrm{mm})$. Ten cylinders per sample were analysed for each test.

\subsection{Expressible moisture}

Expressible moisture (EM) of swede roots cylinders was determined according with Trejo-Araya et al. (2009). Swede cylinders of $11 \times 11 \mathrm{~mm}$ (diameter $\times$ length) were used to measure EM. The surface of each sample was dried using tissue paper and weighed before analysis. Filter papers (Whatman No. 1, $55 \mathrm{~mm}$ diameter) employed to absorb the released water were also weighed. EM was measured with a TA-XT2i texture analyser by compressing a cylinder placed in vertical position between two filter papers. The test was performed at a compression rate of $1 \mathrm{~mm} / \mathrm{s}$ and $70 \%$ strain. After compression, filter papers were weighed immediately. EM was measured as the weight 
122 difference of the filter papers before and after compression divided by the original sample weight. Five cylinders per sample were analysed.

124

125

\subsection{Colour measurements}

Swede colour was measured with a HunterLab spectrophotometer (Ultrascan XE, Hunter Associates Laboratory, Inc., Reston, VA) with a D65 illuminant and $10^{\circ}$ standard observer angle. Colour coordinates were determined using the 1976 CIELAB system and the results were expressed as $\mathrm{L}^{*}$ (lightness), $\mathrm{a}^{*}$ (redness) and $\mathrm{b}^{*}$ (yellowness). The instrument was calibrated before each series of measurements using white $\left(\mathrm{L}^{*}=100\right)$ and black $\left(\mathrm{L}^{*}=0\right)$ standard tiles. A numerical total colour difference $(\Delta \mathrm{E})$ was calculated as suggested by Jung Ghoul \& de Lamballerie-Anton (2003):

$$
\Delta \mathrm{E}=\left[\left(\mathrm{L}^{*}-\mathrm{L}_{0} *\right)^{2}+\left(\mathrm{a}^{*}-\mathrm{a}_{0} *\right)^{2}+\left(\mathrm{b}^{*}-\mathrm{b}_{0} *\right)^{2}\right]^{1 / 2}=\left[(\Delta \mathrm{L} *)^{2}+\left(\Delta \mathrm{a}^{*}\right)^{2}+\left(\Delta \mathrm{b}^{*}\right)^{2}\right]^{1 / 2}
$$

The colour values of non-treated samples $\left(\mathrm{L}_{0} *, \mathrm{a}_{0} *\right.$, and $\left.\mathrm{b}_{0} *\right)$ were used as reference values for $\Delta \mathrm{E}$ calculation. Three colour measurements per sample were taken.

\subsection{Sample extraction}

Lyophilised samples were milled to a fine powder using a blender (BL440001, Kenwood limited, Hampshire, U.K.) and extracted by pressurised liquid extraction (PLE) using an Accelerated Solvent Extractor (ASE 200, Dionex, Idsteinn, Germany) equipped with a solvent controller. Cellulose filters (Dionex, Idsteinn, Germany) were inserted at top and bottom of $22 \mathrm{ml}$ extraction cells. One gramme of sample powder mixed with $4 \mathrm{~g}$ of silica (Merck grade, $60 \AA$, sigma Aldrich, St. Louis, USA) was packed on top of $0.4 \mathrm{~g}$ of diatomaceous earth into each cell. PLE variables were set according to Mohn, Cutting, Ernst \& Hamburger (2007); preheat time: 1 min; static extraction per cycle: 5 min; flush: $100 \%$ of cell volume; purge: $80 \mathrm{~s}$ with nitrogen; pressure: $120 \mathrm{bar}$, temperature: $50{ }^{\circ} \mathrm{C}$, extraction time: $3 \times 5$ min cycles; $70 \%$ methanol in water was used as extraction solvent. After collection in $60 \mathrm{ml}$ vials the extracts were filtered through PTFE syringe filters (pore size $0.45 \mu \mathrm{m}$, Sigma Aldrich, St. Louis, USA) and stored at $80{ }^{\circ} \mathrm{C}$ until analysis. Three extracts of each sample were obtained for further analysis.

\subsection{Ascorbic acid analysis}

Ascorbic acid content in root swedes was determined as was described by Tiwari, O'Donnell, Patras \& Cullen (2008). Extracts were obtained by dissolving $0.15 \mathrm{~g}$ of freeze dried powder in $10 \mathrm{ml}$ of $6 \%$ metaphosphoric acid. After vortexing 
mixture was centrifuged at 2,000g for $10 \mathrm{~min}$ at $4{ }^{\circ} \mathrm{C}$ (Sanyo MSE Mistral 3000ii, Sanyo). Five millilitres of the supernatant was filtered through PTFE syringe filters (pore size $0.45 \mu \mathrm{m}$, Sigma Aldrich, St. Louis, USA) and placed in an autosampler vial. The chromatographic system was composed by a Waters (Milford, MA, USA) 600s controller, a Waters 717plus autosampler, a Waters 616 pump equipped with a hypersil ODS guard column (Gemini C18, Phenomenex., UK), and an hypersil ODS column $(15 \mathrm{~cm} \times 4.6 \mathrm{~cm}, 5 \mu \mathrm{m}$,

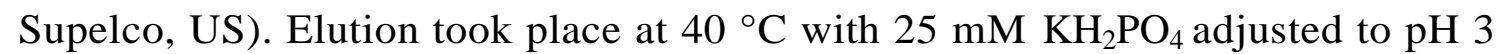
with $\mathrm{H}_{3} \mathrm{PO}_{4}$, at a flow rate of $1 \mathrm{ml} / \mathrm{min}$. The eluate was monitored with a Waters 486 turnable absorbance detector (Milford, MA, USA) set at $245 \mathrm{~nm}$. Millennium 32 software from Waters (Milford, MA, USA) was used for peak integration. A calibration curve of ascorbic acid $(25-500 \mu \mathrm{g} / \mathrm{ml})$ in metaphosphoric acid (6\%) was used for quantification. Each extract was analysed in triplicate and average was employed for calculation.

\subsection{Total phenol analysis}

Total phenolic content of swede root was assessed using a modified version of the Folin-Ciocalteu assay (Singleton, Orthofer, \& Lamuela-Raventos, 1999). $100 \mu 1$ of PLE extract or gallic acid standard, $100 \mu \mathrm{l}$ of methanol, $100 \mu \mathrm{l}$ of Folin-Ciocalteu reagent and $700 \mu \mathrm{l}$ of $\mathrm{Na}_{2} \mathrm{CO}_{3}$ were mixed in $1.5 \mathrm{ml}$ centrifuge tubes. Vortexed samples were left in the dark for $20 \mathrm{~min}$ at room temperature. After centrifugation at 13,000 rpm for 3 min the absorbance of supernatant was measured at $735 \mathrm{~nm}$ using a spectrophotometer (UV- 1700 Pharma Spec, Shimadzu, Japan). Total phenol concentration was calculated using a standard calibration curve with gallic acid (10-400 mg/l), and expressed as $\mathrm{mg}$ gallic acid equivalent/100g dry weight (mg GAE/100g DW). Each extract was analysed in triplicate and average was employed for calculation.

\subsection{Total antioxidant capacity}

Total antioxidant capacity was measured using the DPPH assay described by Wijngaard, Rossle \& Brunton (2009). At first serial dilutions of swede PLE extracts with methanol were prepared. Analysis was realised by adding $500 \mu 1$ of diluted extracts to $500 \mu \mathrm{l}$ of DPPH working solution $(0.048 \mathrm{mg} / \mathrm{ml})$, and after vortexing, the samples were left in the dark for $30 \mathrm{~min}$ at room temperature. Absorbance was measured against methanol at $515 \mathrm{~nm}$ using a spectrophotometer (UV- 1700 Pharma Spec, Shimadzu, 
Milton Keynes). Antioxidant capacity was referred to a synthetic antioxidant, Trolox, and expressed as Trolox equivalent antioxidant capacity value (TEAC), using the formula TEAC $=\left(\mathrm{IC} 0_{\text {Trolox }} / \mathrm{IC} 50_{\text {Sample }}\right) \times 10^{5}$ where $\mathrm{IC}_{50}$ is the concentration of sample extract needed to obtain a depletion of $50 \%$ in the original absorbance of DPPH. Each extract was analysed in triplicate and average was employed for calculation.

\subsection{Glucosinolate analysis}

Two millilitres of PLE extract was evaporated to dryness under nitrogen and redissolved in $0.5 \mathrm{ml}$ of $70 \%$ methanol in water. Concentrated extract was filtered through hydrophilic polyethersulfone membrane (Millex MP, pore size $0.22 \mu \mathrm{m}$, Millipore, Massachusetts, US), and analysed according to Prestera et al. (1996). Glucosinolates were analysed with paired-ion chromatography (Agilent series 1100 HPLC) using a $\mu$-Bondapak C18 reverse phase column (3:9 x $300 \mathrm{~mm})$ connected to a $\mu$-Bondapak C18 Guard-pak (Waters, Melford, MA, USA) set at $3 \mathrm{ml} / \mathrm{min}$ and monitoring at 235 and $245 \mathrm{~nm}$. The mobile phase employed was $0.005 \mathrm{M}$ TDAB dissolved in acetonitrile/water (1:1). Sinigrin was employed as external standard, a calibration curve of sinigrin was made $(0.016-1 \mathrm{mg} / \mathrm{ml})$. The quantification of each glucosinolate was estimated as suggested by Fahey, Zhang \& Talalay (1997) and Shapiro et al. (2001). Each extract was analysed in triplicate and average was employed for calculation.

\subsection{Data analysis}

All statistical analyses were performed using the SAS Enterprise Guide version 4 (Statistical Analytical Systems Institute, Cary, NC, USA). Two different models were applied. The first model included treatment (NT, blanching, $200 \mathrm{MPa}$ at $20^{\circ} \mathrm{C}, 200 \mathrm{MPa}$ at $40^{\circ} \mathrm{C}, 400 \mathrm{MPa}$ at $20^{\circ} \mathrm{C}, 400 \mathrm{MPa}$ at $40^{\circ} \mathrm{C}, 600 \mathrm{MPa}$ at $20^{\circ} \mathrm{C}$, and $600 \mathrm{MPa}$ at $40^{\circ} \mathrm{C}$ ) as a fix effect. The second model only considered pressurised samples, and included temperature, pressure and temperature $\times$ pressure interaction as fixed effects. No significant interactions $(\mathrm{p}>0.05)$ were dropped from the model. Differences were assessed by the Tukey test $(\mathrm{p}<0.05)$. Pearson correlation analysis was used to investigate the relationship among the studied parameters. 


\section{Results and discussion}

218

219

220

221

222

223

224

225

226

227

228

229

230

231

232

233

234

235

236

237

238

239

240

241

242

243

244

245

246

247

248

249

\subsection{Texture}

Food processing is known to critically affect the texture of vegetables. Processing of vegetables brings on mechanical damage that leads to turgor loss and induces alteration of pectin structure and function caused by both enzymatic and chemical processes, such as B-elimination (Buggenhout, Sila, Duvetter, Loey, \& Hendrickx, 2009; Greve, McArdle, Gohlke, \& Labavitch, 1994). The impact of processing on swede texture was assessed using a compression and a cutting test. The compression test gives a measure of hardness related to the force needed to compress a tissue. After processing, the hardness of swede decreased $(\mathrm{p}<0.001)$ with all treatments assayed (Fig. 1). Pressurisation at $200 \mathrm{MPa}$ and $40^{\circ} \mathrm{C}$ allowed better hardness retention than all other treatments but $600 \mathrm{MPa}$ and $40{ }^{\circ} \mathrm{C}$. Blanching and HPP at 200 and $600 \mathrm{MPa}$ and $20{ }^{\circ} \mathrm{C}$ showed similar hardness values $(\mathrm{p}>0.05)$. Finally, the softest texture was achieved at $400 \mathrm{MPa}$. Softening of vegetables induced by heat and pressure treatments seems to follow different patterns. Texture changes in blanched vegetables are not associated with enzyme activity, as most vegetable enzymes are inactivated at the conditions used for blanching. The initial loss of hardness induced by thermal processes such as blanching is related with loss of turgor due to membrane disruption (Greve et al., 1994). However, the main contributing factor to tissue softening during thermal processing (Sila, Smout, Elliot, Loey, \& Hendrickx, 2006; Vu, Smout, Sila, Loey, \& Hendrickx, 2006) is the reduction of adhesion between cells due to the solubilisation of pectin by $\beta$ elimination reaction. Similar texture losses than those obtained in the present study were reported by Moreira, Oliveira, Oliveira \& Singh (1994) after thermal treatment of turnip (Brassica rapa).

Differently, high pressure processing results in minimal pectin solubilisation (Oey, Lille, et al., 2008). Textural changes in vegetables induced by HPP are mainly caused by mechanical damage and changes on enzyme activity. The results of the compression test suggest that the degree of cell disruption was dependent on the applied level of pressure. These results are in agreement with previous observations reporting strong firmness loss after HPP in a range of 100-400 MPa of different vegetables (Basak \& Ramaswamy, 1998). Trejo-Araya et al. (2007) reported no further reduction of hardness in carrots above $300 \mathrm{MPa}$. The authors suggested that above a certain pressure threshold (which will be product structure dependent) tissue might not further compress or be 
disrupted. The reported results, showing a decrease of hardness with pressures up to 400 MPa (Fig. 1) suggest that the compression threshold for swede would be higher than in the case of carrots. After processing at $600 \mathrm{MPa}$, higher values of hardness were observed compared to $400 \mathrm{MPa}$. Similarly, Tangwongchai, Ledward, and Ames (2000) also reported less apparent damage in tomato at pressure levels above $400 \mathrm{MPa}$. The authors reported inactivation of polygalacturonase (PG) at $500 \mathrm{MPa}$ and above. Inactivation of enzymes related to softening of vegetables such as PG would explain the apparent texture recovery at $600 \mathrm{MPa}$.

Changes on texture were also measured with the cutting test. The cutting test can give information on other parameters such as the resistance of a tissue to fracture, determined by the maximum force during the cutting test, and tissue elasticity, measured by the increase of both cutting force and displacement (Trejo-Araya et al., 2007). The results of the cutting test are shown in Fig. 2. HPP at $600 \mathrm{MPa}$ presented similar ( $p>0.05)$ values of cutting force and displacement than non-treated (NT) samples (Fig. 2), suggesting that this pressure level would not alter the cutting properties of swede. HPP at $400 \mathrm{MPa}$ induced the highest increase in cutting force and displacement values. On the contrary, blanching and HPP at $200 \mathrm{MPa}$ induced a reduction of cutting force compared to NT samples. Higher values of cutting force have been related with more deformable materials, with less cell integrity and hence more rubbery-like texture, as part of the cutting force is used to deform the material (Dowgiallo, 2005; Trejo-Araya et al., 2007).

From the reported results it can be extracted that HPP at $400 \mathrm{MPa}$ would have induced the greater textural changes in swede, resulting in a softer and more rubbery-like texture. On the contrary, HPP at $600 \mathrm{MPa}$ proved to be the treatment that better preserved the texture of swede. In agreement to our results, other authors have reported less alteration of texture after processing carrots at $600 \mathrm{MPa}$ compared to a mild heat treatment (Trejo-Araya et al., 2009).

On the other hand, a significant effect of the pressurisation temperature on swede texture was observed at 200 and $400 \mathrm{MPa}$ (Fig. 1). Swede samples treated at $40^{\circ} \mathrm{C}$ were harder than those treated at $20^{\circ} \mathrm{C}$. These results would suggest greater enzyme inactivation at higher pressurisation temperature. In agreement with this, Fachin, Smout, Verlent, Ly-Nguyen, Van Loey, and Hendrickx (2004) reported higher inactivation of PG by increasing the pressurisation temperature in pressurised purified tomato PG 
treated at fixed pressure. On the contrary, no differences were observed between both pressurisation temperatures at $600 \mathrm{MPa}$. This observation would be consistent with higher enzyme inactivation at higher pressure levels, independently on the pressurisation temperature. This result would be consistent with the observed inactivation of PG reported previously in diced tomato with $\mathrm{HPP}$ at $600 \mathrm{MPa} / 25^{\circ} \mathrm{C}$ during 3 min (Shook, Shellhammer, \& Schwartz, 2001).

\subsection{Expressible moisture}

Expressible moisture (EM) of swede was measured as the water released from swede upon compression at $70 \%$ strain. EM would be a measure of the water binding capacity (WBC) of swede; a higher EM would indicate a lower WBC of the product. The EM of vegetables is related to the cellular structure, turgidity, integrity and cell wall strength (Trejo-Araya et al., 2009). Fig. 3 shows an increase of EM of swede $(p<0.001)$ after all studied treatments, indicating a loss of WBC as a consequence of processing. Pressurisation at $600 \mathrm{MPa}$ and $20^{\circ} \mathrm{C}$ was the treatment that altered the $\mathrm{EM}$ of swede to a lesser extent. Blanching exhibited higher EM than pressurised samples, with the exception of HPP at $400 \mathrm{MPa}$ and $20^{\circ} \mathrm{C}$. Other authors have reported increases in EM in blanched and pressurised vegetables (Trejo-Araya et al., 2009). A soaked appearance has been observed in pressurised vegetables (Prestamo \& Arroyo, 1998; Tangwongchai et al., 2000). This phenomenon has been related to the disturbance of cell permeability, permitting transport of water from inside to outside of the cell (Prestamo \& Arroyo, 1998). Results of EM of samples HPP at $20^{\circ} \mathrm{C}$ are in agreement with those of Prestamo and Arroyo (1998) and Tangwongchai et al. (2000), who reported higher water losses in a pressure range of $200-400 \mathrm{MPa}$ than at 500-600 $\mathrm{MPa}$.

Among pressurised samples, the lower pressures used (200-400 MPa) showed lower EM after processing at $40{ }^{\circ} \mathrm{C}$ than at $20^{\circ} \mathrm{C}$. The better retention of water binding properties observed when processing at $40^{\circ} \mathrm{C}$ compared to $20^{\circ} \mathrm{C}$ at 200 and $400 \mathrm{MPa}$, suggest that HPP at higher temperature would induce less structural changes in swede. These results agree with those reported for hardness, where swede treated at 200 and $400 \mathrm{MPa}$ showed less alteration of texture at $40^{\circ} \mathrm{C}$ compared to $20^{\circ} \mathrm{C}$. Moreover, a significant negative correlation observed between EM values and the compression force ( $\mathrm{p}<0.0001 ; \mathrm{r}=-0.86690)$ would further confirm this relationship. 


\subsection{Colour parameters}

316 Processing of swede (HPP and blanching) induced a significant reduction of most

317 colour coordinates (Table 1). The changes in $\mathrm{L}^{*}$ (lightness) values were the most 318 pronounced. Table 1 shows lower total colour changes $(\Delta \mathrm{E})$ in blanched swede 319 compared to HPP. Among pressurised samples, no significant interaction between the 320 pressure level and the pressurisation temperature was observed (data not shown). 321 Therefore, interaction between pressure and temperature was dropped from the model 322 for colour values. Statistical analysis showed a significant effect of the pressure level 323 applied on colour coordinates (Table 2). HPP at $200 \mathrm{MPa}$ showed the highest a* 324 (redness) and $\Delta \mathrm{E}$ values and the lowest $\mathrm{L}^{*}$ values among pressure treatments. On contrary, no differences among pressure treatments $(\mathrm{p}>0.05)$ were observed for the $\mathrm{b}^{*}$ (yellowness) coordinate (data not shown).

The influence of HPP on the $\mathrm{L}^{*}$ coordinate of vegetables can be partly related to structural changes, since texture alterations may affect the extent of internally scattered light and the distribution of surface reflectance (Oey, Lille, et al., 2008). Results for compression force were positively correlated with $L^{*}(p<0.001 ; r=0.839)$, while values of displacement at maximum cutting force were negatively correlated with $\mathrm{L}^{*}$ values $(\mathrm{p}<0.01 ; \mathrm{r}=-0.608)$. Confirming that pressure induced changes on the texture of swede could have influenced colour changes to some extent. Other possible causes of colour changes after processing of vegetables may be due to changes in the activity of enzymes such as peroxidases (Burnette, 1977; Ueno, Hayashi, Shigematsu, \& Fujii, 2009). In this sense, swede roots are rich in peroxidases (Baardseth \& Slinde, 1980). Eisenmenger and Reyes-De-Corcuera (2009) reported activation of peroxidases in carrots HPP between 300 and $500 \mathrm{MPa}$. According to this, stronger alteration of swede colour (a* coordinate) at 400 and $600 \mathrm{MPa}$ could be related to activation of enzymes such as peroxidases. In contrast, swede peroxidases have been reported to be inactivated by blanching (Baardseth \& Slinde, 1980). This fact would explain the better colour retention observed in blanched swede compared to HPP. Ueno et al. (2009) reported the formation of green-blue compounds in pressurised turnip (B. rapa) after one week of storage. The authors related its formation either to the partial destruction of cellular membrane structures by pressure or to the activity of enzymes such as peroxidases. 


\subsection{Ascorbic acid}

348 Among root vegetables, swedes are known to be a valuable source of ascorbic acid 349 (Paul \& Southgate, 1978). However, ascorbic acid is a labile compound greatly affected during vegetable processing. All studied treatments induced a significant decrease in ascorbic acid (AA) content of swede (Table 3). Maximum retention of AA was observed after blanching and HPP at $600 \mathrm{MPa}$ (ca. 81-67\% retention). HPP at $200 \mathrm{MPa}$ showed lower values, although not significant, of AA than pressurisation at $600 \mathrm{MPa}$. Swede samples pressurised at $400 \mathrm{MPa}$ resulted in the lowest values in AA content (Table 3). No significant effect of the pressurisation temperature on the AA content of swede was observed $(\mathrm{p}>0.05)$.

AA is an antioxidant compound very soluble in water and with low thermal stability (Podsedek, 2007). Losses of vitamin C occur primarily by chemical degradation, which is speed at higher temperatures (Dewanto, Wu, Adom, \& Liu, 2002). Therefore, losses of AA due to thermal degradation and leaching were expected in blanched swede. Similarly, previous studies have reported heat induced losses of AA in other species of Brassica (Olivera et al., 2008). The effect of HPP in AA content has also been reported previously, although sensitivity of AA towards pressure and temperature has proved to be dependent on the environment (Oey, Van der Plancken, et al., 2008). Our results are in agreement with other authors that observed more pronounced AA losses at $400 \mathrm{MPa}$ than at $600 \mathrm{MPa}$ in strawberry purées $\left(15 \mathrm{~min}\right.$ at $\left.20^{\circ} \mathrm{C}\right)$ and in green peas $(5 \mathrm{~min}$ at 33.5 - $42.5^{\circ} \mathrm{C}$ ) (Patras, Brunton, Da Pieve, \& Butler, 2009; Quaglia, Gravina, Paperi, \& Paoletti, 1996).

Krebbers et al (2002) suggested that the breakdown of AA after HPP was mainly the result of chemical breakdown. Disruption of cell walls by HPP would release oxidative species and subsequently would increase diffusion and reaction rate of substrates. Strong correlations $(\mathrm{p}<0.001)$ between texture measurements and AA content were observe in both compression force $(r=0.72673)$ and displacement at maximum cutting force $(\mathrm{r}=-0.810)$, confirming the relationship between cell damage and AA content.

\subsection{Total Phenol}

376 Vegetables from the Brassica family are known to present strong antioxidant properties 377 (Podsedek, 2007). Table 3 shows the total phenol (TP) content present in swede 378 samples. Pressurisation at $600 \mathrm{MPa}$ and $20{ }^{\circ} \mathrm{C}$ had no significant effect on TP values 
compared to NT samples. All other treatments induced a significant reduction of TP content of swede. HPP at $200 \mathrm{MPa}$ and $40{ }^{\circ} \mathrm{C}$, and $400 \mathrm{MPa}$ at both temperatures resulted in the lowest values of TP.

The decrease of the TP content of vegetables due to thermal treatment is a well known phenomenon (Roy et al., 2007). It could be due either to leaching losses or to chemical degradation of phenols, being their losses dependent on both the vegetable studied and the intensity of the treatment (Roy et al., 2007) The effect of HPP on TP content have also shown very different responses depending on the type of vegetable and the pressure treatment applied (Oey, Van der Plancken, et al., 2008). Decrease in TP content has been reported in strawberries treated at 300-600 $\mathrm{MPa}$ and $20-60{ }^{\circ} \mathrm{C}$ for $2-10 \mathrm{~min}$ (Terefe, Matthies, Simons, \& Versteeg, 2009). Other studies have shown no TP differences in pressurised onions (400 MPa/ 5-50 ${ }^{\circ} \mathrm{C} / 30 \mathrm{~min}$ ) (Roldan-Marin, SanchezMoreno, Lloria, de Ancos, \& Cano, 2009), while HPP of strawberry purée (600 MPa/ $15 \mathrm{~min} / 22^{\circ} \mathrm{C}$ ) showed increased TP values (Patras et al., 2009). The decrease of phenolic compounds observed with pressure may be related to the enhancement of the chemical oxidation of polyphenols, since swede does not contain the polyphenol oxidase system (Boswell, 1950). As previously stated, cell disruption entailed by HPP would release substrates and promote changes in TP content, as shown by significant correlations $(\mathrm{p}<0.001)$ with both compression force $(\mathrm{r}=0.650)$ and displacement at maximum cutting force $(\mathrm{r}=-0.649)$. Another contributory factor to changes on TP content may be related to changes on AA, since this molecule can react with the reactive Folin-Ciocalteu reagent (Prior, Wu, \& Schaich, 2005). TP content showed a strong correlation $(\mathrm{p}<0.001)$ with AA content $(\mathrm{r}=0.752)$. Therefore, the reported reduction of AA could have influenced the reduction of TP content to some extent. On the contrary, increase of TP content at $600 \mathrm{MPa}$ has been related with increased extractability at higher pressures (Patras et al., 2009). According to this, the little effect on the TP content observed after processing at $600 \mathrm{MPa}$ and $20^{\circ} \mathrm{C}$ may be due to increased extractability at this pressure level, which could have counterbalanced the losses of phenols caused by pressure induced oxidation.

\subsection{Total antioxidant capacity}

Table 3 shows results for the total antioxidant capacity of swede, measured as DPPH scavenging capacity and referred as Trolox equivalent antioxidant capacity value (TEAC). All treatments produced a significant decrease of antioxidant capacity of 
412 swede, except HPP at $600 \mathrm{MPa}$ and $20^{\circ} \mathrm{C}$. This treatment together with blanching 413 showed higher antioxidant capacity $(\mathrm{p}<0.001)$ than other pressure treatments. The loss 414 in antioxidant capacity due to thermal treatment it is well known (Roy et al., 2007). This 415 decrease, as previously stated, can be due to leaching losses or to the degradation of 416 antioxidant compounds accelerated by high temperatures (Roy et al., 2007).

417 Among pressurised samples, no significant interaction between the pressure level and 418 the pressurisation temperature was observed (data not shown). Therefore, interaction 419 between pressure and temperature was dropped from the model for total antioxidant 420 analysis. Statistical analysis revealed that the pressure level applied had a significant effect $(\mathrm{p}<0.001)$ on TEAC values of swede. HPP at $600 \mathrm{MPa}$ showed the highest total antioxidant capacity among pressurised swede (Table 2). Pressurisation at $400 \mathrm{MPa}$ proved to be most severe pressure treatment with regard to TEAC values. No studies about the effect of HPP on the antioxidant capacity of swede roots have been found. In agreement with our findings, McInerney, Seccafien, Stewart, and Bird (2007) and Patras et al. (2009) observed a decrease in antioxidant activity of carrots and strawberry purée, respectively, treated at $400 \mathrm{MPa}$, while no variations were reported at $600 \mathrm{MPa}$. However, HPP at $600 \mathrm{MPa}$ of other vegetables and fruits (green beans and blackberry purée) induced an increase in antioxidant capacity (McInerney et al., 2007; Patras et al., 2009). According to that, the effect of high pressure on antioxidant capacity would depend not only on the pressurisation conditions but also on the type of vegetable studied.

Total antioxidant capacity showed a positive correlation $(\mathrm{p}<0.001)$ with both AA content $(r=0.880)$ and total phenol content $(r=0.650)$. This result suggests that changes in total antioxidant capacity during processing of swede were related to changes in both compounds with antioxidant properties and textural changes.

\subsection{Glucosinolate content}

Glucosinolates (GLS) are a group of secondary plant metabolites found in high concentrations in Brassica vegetables (Oerlemans, Barrett, Suades, Verkerk, \& Dekker, 2006). Glucosinolates are of particular interest in food research because of their health

441 benefits. The products derived from the hydrolysis of GLS have a potential 442 anticarcinogenic effect and beneficial effects for the health (Fahey, Zalcmann, \& Talalay, 2001). However, high concentrations of some GLS in vegetables, such as 
progoitrin, can have toxic effects. Therefore, monitoring the behaviour of glucosinolates after vegetable processing becomes essential (Van Eylen et al., 2009).

Four glucosinolates were found in sufficient amount for quantification in non-treated swede (Table 3): glucoraphanin, progoitrin and glucobrassicanapin, that are aliphatic GLS, and glucobrassicin, an indol GLS. Processing of swede caused no significant effect in glucoraphanin content (Table 3). Likewise, progoitrin content was not affected (p>0.05) by blanching and HPP at $200 \mathrm{MPa}$. HPP at higher pressure levels (400 and 600 $\mathrm{MPa})$, though, induced an increase of progoitrin levels $(\mathrm{p}<0.001)$. It should be noted that despite the increased presence of progoitrin, all samples analysed showed progoitrin levels below the threshold that could involve a health risk to consumers (Fahey et al., 2001; Oerlemans et al., 2006). Glucobrassicanapin content was reduced $(\mathrm{p}<0.001)$ with all studied treatments. Similarly, processing of swede at all conditions studied induced a significant reduction of glucobrassicin content. However, blanching was the treatment that better preserved the content of this indol GLS (Table 3). Similar to our results, Van Eylen et al. (2009) reported losses of glucobrassicanapin and glucobrassicin glucosinolates after conventional treatments of broccoli heads $\left(100{ }^{\circ} \mathrm{C}\right)$. The authors related the losses to thermal degradation of GLS or to leaching losses. Our results confirm the different thermolability among the studied GLS. As previously observed, progoitrin and glucoraphanin proved to be less thermolabile than glucobrassicin and glucobrassicanapin (Oerlemans et al., 2006). These results suggest that the observed decrease of GLS in blanched swede would be more likely due to thermal degradation.

On the contrary, the decrease of GLS content with high pressure processing has been attributed to their hydrolysis. A higher cell disruption favoured by HPP would allow contact of enzyme myrosinase with GLS, resulting in their hydrolysis into health beneficial compounds (Van Eylen et al., 2009). Therefore, the effect of HPP on GLS is dependent on the changes induced on cell structure and on myrosinase activity (Van Eylen et al., 2009). From the above mentioned, it derives that the reported decrease of 472 glucobrassicanapin and glucobrassicin in pressurised samples would be related to 473 enhanced hydrolysis of these glucosinolates by high pressure. Glucobrassicanapin and glucobrassicin contents showed a positive correlation $(\mathrm{p}<0.001)$ with swede hardness ( $r=0.766$ and $r=0.744$, respectively), suggesting the relationship between higher cell disruption and higher GLS hydrolysis. 
477 The reported results would suggest the potential health benefit of HPP of swede by 478 increasing hydrolysis of GLS. Further study on the hydrolysis compounds derived of 479 HPP of swede would help to shed light on the exact mechanisms promoting pressure induced hydrolysis of GLS.

481

482

\section{Conclusions}

483 From the reported results, it can be concluded that both processing technologies 484 (blanching and HPP) altered the physical and nutritional properties of swede. High 485 pressure processing at $400 \mathrm{MPa}$ induced the strongest alteration on swede quality. The 486 results suggest that the strong structural modifications induced by HPP at $400 \mathrm{MPa}$ 487 would have played a role in the alteration of antioxidant properties of swede. In general, 488 blanching (thermal treatment) and HPP at 600 and $20^{\circ} \mathrm{C}$ were the treatments that better 489 preserved swede quality traits. Therefore, this pressure treatment could be considered as 490 a possible alternative to blanching for swede processing. Moreover, the possible 491 hydrolysis of glucosinolates by high pressure, could promote beneficial health effects 492 on pressurised swede. Further study on this direction would be necessary to confirm this 493 hypothesis.

494

495 Acknowledgements

496 Maria Clariana is a recipient of a pre-doctoral fellowship and a mobility grant funded by 497 the Spanish Instituto Nacional de Investigación y Tecnología Agraria y Alimentaria. 498 This research was funded under the Irish National Development Plan under the Food 499 Institutional Research Measure, administered by the Department of Agriculture, $500 \quad$ Fisheries and Food. 
503 Baardseth, P., \& Slinde, E. (1980). Heat inactivation and pH optima of peroxidase and 504 catalase in carrot, swede and Brussels sprouts. Food Chemistry, 5, 169-174.

505 Basak, S., \& Ramaswamy, H. S. (1998). Effect of high pressure processing on the 506 texture of selected fruits and vegetables. Journal of Texture Studies, 29, 587-601.

507 Boswell, J. G. (1950). Metabolic Systems in the "Root" of Brassica napus L.. Annals of 508 Botany, 14, 521-543.

509 Buggenhout, S. V., Sila, D. N., Duvetter, T., Loey, A. V., \& Hendrickx, M. (2009). 510 Pectins in Processed Fruits and Vegetables: Part III-Texture Engineering.

511 Comprehensive Reviews in Food Science and Food Safety, 8, 105-117.

512 Burnette, F. S. (1977). Peroxidase and its relationship to food flavor and quality: a 513 review. Journal of Food Science, 42, 1-6.

514 Cano, M. P., Hernandez, A., \& Ancos, B. (1997). High Pressure and Temperature 515 Effects on Enzyme Inactivation in Strawberry and Orange Products. Journal of Food 516 Science, 62, 85-88.

517 Castro, S. M., Saraiva, J. A., Lopes-Da-Silva, J. A., Delgadillo, I., Van Loey, A., 518 Smout, C., \& Hendrickx, M. (2008). Effect of thermal blanching and of high pressure 519 treatments on sweet green and red bell pepper fruits (Capsicum annuum L.). Food 520 Chemistry, 107, 1436-1449.

521 Dewanto, V., Wu, X. L., Adom, K. K., \& Liu, R. H. (2002). Thermal Processing 522 Enhances the Nutritional Value of Tomatoes by Increasing Total Antioxidant Activity. 523 Journal of Agricultural and Food Chemistry, 50, 3010-3014.

524 Dowgiallo, A. (2005). Cutting force of fibrous materials. Journal of Food Engineering, $52566,57-61$.

526 Eisenmenger, M. J., \& Reyes-De-Corcuera, J. I. (2009). High pressure enhancement of 527 enzymes: A review. Enzyme and Microbial Technology, 45, 331-347.

528 Eshtiaghi, M. N., \& Knorr, D. (1993). Potato Cubes Response to Water Blanching and 529 High Hydrostatic Pressure. Journal of Food Science, 58, 1371-1374. 
530 Fachin, D., Smout, C., Verlent, I., Ly-Nguyen, B., Van Loey, A., \& Hendrickx, M. E. 531 (2004). Inactivation Kinetics of Purified Tomato Polygalacturonase by Thermal and 532 High-Pressure Processing. Journal of Agricultural and Food Chemistry, 52, 2697-2703.

533 Fahey, J. W., Zalcmann, A. T., \& Talalay, P. (2001). The chemical diversity and 534 distribution of glucosinolates and isothiocyanates among plants. Phytochemistry, 56, 553551

536 Fahey, J. W., Zhang, Y., \& Talalay, P. (1997). Broccoli sprouts: An exceptionally rich 537 source of inducers of enzymes that protect against chemical carcinogens. Proceedings of 538 the National Academy of Sciences of the United States of America, 94, 10367-10372.

539 Greve, L. C., McArdle, R. N., Gohlke, J. R., \& Labavitch, J. M. (1994). Impact of 540 Heating on Carrot Firmness: Changes in Cell Wall Components. Journal of Agricultural 541 and Food Chemistry, 42, 2900-2906.

542 Grubben, G. J. H., \& Denton, O. A. (2004). Plant resources of tropical Africa 2. 543 Vegetables. Leiden Netherlands/CTA, Wageningen, Netherlands: PROTA Foundation; 544 Backhuys Publishers, 127-130.

545 Hendrickx, M. E., Ludikhuyze, L., Van den Broeck, I., \& Weemaes, C. (1998). Effects 546 of high pressure on enzymes related to food quality. Trends in Food Science \& 547 Technology, 9, 197-203.

548 Jung, S., Ghoul, M. \& Lamballerie-Anton, M.(2003). Influence of high pressure on the 549 color and microbial quality of beef meat. Lebensmittel-Wissenschaft und-Technologie, $55036,625-631$.

551 Krebbers, B., Koets, M., van den Wall, F., Matser, A. M., Moezelaar, R., \& 552 Hoogerwerf, S. W. (2002). Effects of high-pressure processing on the quality of green 553 beans. Trends in High Pressure Bioscience and Biotechnology, Proceedings, 19, 389554396.

555 Lee, H. S., \& Coates, G. A. (1999). Measurement of total vitamin C activity in citrus 556 products by HPLC: A review. Journal of Liquid Chromatography \& Related 557 Technologies, 22, 2367-2387.

558 McInerney, J. K., Seccafien, C. A., Stewart, C. M., \& Bird, A. R. (2007). Effects of 559 high pressure processing on antioxidant activity, and total carotenoid content and 
560

availability, in vegetables. Innovative Food Science \& Emerging Technologies, 8, 543548.

Mohn, T., Cutting, B., Ernst, B., \& Hamburger, M. (2007). Extraction and analysis of intact glucosinolates - A validated pressurized liquid extraction/liquid chromatographymass spectrometry protocol for Isatis tinctoria, and qualitative analysis of other cruciferous plants. Journal of Chromatography A, 1166, 142-151.

Moreira, L. A., Oliveira, F. A. R., Oliveira, J. C., \& Singh, R. P. (1994). Textural changes in vegetables during thermal-processing .2. Effects of acidification and selected pretreatments on texture of turnips. Journal of Food Processing and Preservation, 18, 497-508.

Oerlemans, K., Barrett, D. M., Suades, C. B., Verkerk, R., \& Dekker, M. (2006). Thermal degradation of glucosinolates in red cabbage. Food Chemistry, 95, 19-29.

Oey, I., Lille, M., Loey, A. v., \& Hendrickx, M. (2008). Effect of high-pressure processing on colour, texture and flavour of fruit- and vegetable-based food products: a review. Trends in Food Science \& Technology, 19, 320-328.

Oey, I., Van der Plancken, I., Van Loey, A., \& Hendrickx, M. (2008). Does high pressure processing influence nutritional aspects of plant based food systems? Trends in Food Science \& Technology, 19, 300-308.

Olivera, D. F., Viña, S. Z., Marani, C. M., Ferreyra, R. M., Mugridge, A., Chaves, A. R., \& Mascheroni, R. H. (2008). Effect of blanching on the quality of Brussels sprouts (Brassica oleracea L. gemmifera DC) after frozen storage. Journal of Food Engineering, 84, 148-155.

Patras, A., Brunton, N. P., Da Pieve, S., \& Butler, F. (2009). Impact of high pressure processing on total antioxidant activity, phenolic, ascorbic acid, anthocyanin content and colour of strawberry and blackberry purees. Innovative Food Science \& Emerging Technologies, 10, 308-313.

Paul, A. A., \& Southgate, D. A. T. (1978). McCance and Widdowson's The composition offoods. Elsevier/North-Holland Biomedical Press (pp. 418).

Podsedek, A. (2007). Natural antioxidants and antioxidant capacity of Brassica vegetables: A review. Food Science and Technology, 40, 1-11. 
590 Prestamo, G., \& Arroyo, G. (1998). High hydrostatic pressure effects on vegetable 591 structure. Journal of Food Science, 63, 878-881.

592 Prestera, T., Fahey, J. W., Holtzclaw, W. D., Abeygunawardana, C., Kachinski, J. L., \& 593 Talalay, P. (1996). Comprehensive chromatographic and spectroscopic methods for the 594 separation and identification of intact glucosinolates. Analytical Biochemistry, 239, 168595179.

596 Prior, R. L., Wu, X. L., \& Schaich, K. (2005). Standardized methods for the 597 determination of antioxidant capacity and phenolics in foods and dietary supplements. 598 Journal of Agricultural and Food Chemistry, 53, 4290-4302.

599 Quaglia, G. B., Gravina, R., Paperi, R., \& Paoletti, F. (1996). Effect of high pressure 600 treatments on peroxidase activity, ascorbic acid content and texture in green peas. Food 601 Science and Technology, 29, 552-555.

602 Roldan-Marin, E., Sanchez-Moreno, C., Lloria, R., de Ancos, B., \& Cano, M. P. (2009). 603 Onion high-pressure processing: Flavonol content and antioxidant activity. Food 604 Science and Technology, 42, 835-841.

605 Roy, M. K., Takenaka, M., Isobe, S., \& Tsushida, T. (2007). Antioxidant potential, anti606 proliferative activities, and phenolic content in water-soluble fractions of some 607 commonly consumed vegetables: Effects of thermal treatment. Food Chemistry, 103, 608 106-114.

609 Shapiro, T. A., Fahey, J. W., Wade, K. L., Stephenson, K. K., \& Talalay, P. (2001). 610 Chemoprotective glucosinolates and isothiocyanates of broccoli sprouts: Metabolism 611 and excretion in humans. Cancer Epidemiology Biomarkers \& Prevention, 10, 501-508.

612 Shook, C. M., Shellhammer, T. H., \& Schwartz, S. J. (2001). Polygalacturonase, 613 Pectinesterase, and Lipoxygenase Activities in High-Pressure-Processed Diced 614 Tomatoes. Journal of Agricultural and Food Chemistry, 49, 664-668.

615 Sila, D. N., Smout, C., Elliot, F., Loey, A. v., \& Hendrickx, M. (2006). Non-enzymatic 616 Depolymerization of Carrot Pectin: Toward a Better Understanding of Carrot Texture 617 During Thermal Processing. Journal of Food Science, 71, E1-E9.

618 Singleton, V. L., Orthofer, R., \& Lamuela-Raventos, R. M. (1999). Analysis of total 619 phenols and other oxidation substrates and antioxidants by means of Folin-Ciocalteu 620 reagent. Methods in Enzymology, 299, 152-178. 
621 Tangwongchai, R., Ledward, D. A., \& Ames, J. M. (2000). Effect of high-pressure treatment on the texture of cherry tomato. Journal of Agricultural and Food Chemistry, $48,1434-1441$.

624

Terefe, N. S., Matthies, K., Simons, L., \& Versteeg, C. (2009). Combined high pressure-mild temperature processing for optimal retention of physical and nutritional quality of strawberries (Fragaria ananassa). Innovative Food Science \& Emerging Technologies, 10, 297-307.

Tiwari, B. K., O'Donnell, C. P., Patras, A., \& Cullen, P. J. (2008). Anthocyanin and ascorbic acid degradation in sonicated strawberry juice. Journal of Agricultural and Food Chemistry, 56, 10071-10077.

631

Trejo-Araya, X. I., Hendrickx, M., Verlinden, B. E., Van Buggenhout, S., Smale, N. J., Stewart, C., \& Mawson, A. J. (2007). Understanding texture changes of high pressure processed fresh carrots: A microstructural and biochemical approach. Journal of Food Engineering, 80, 873-884. Trejo-Araya, X. I., Smale, N., Zabaras, D., Winley, E., Forde, C., Stewart, C. M., \& Mawson, A. J. (2009). Sensory perception and quality attributes of high pressure processed carrots in comparison to raw, sous-vide and cooked carrots. Innovative Food Science \& Emerging Technologies, 10, 420-433.

Ueno, S., Hayashi, M., Shigematsu, T., \& Fujii, T. (2009). Formation of green-blue compounds in Brassica rapa root by high pressure processing and subsequent storage. Bioscience Biotechnology and Biochemistry, 73, 943-945. Van Eylen, D., Bellostas, N., Strobel, B. W., Oey, I., Hendrickx, M. E., Van Loey, A., Sørensen, H., \& Sørensen, J. C. (2009). Influence of pressure/temperature treatments on 644 glucosinolate conversion in broccoli (Brassica oleraceae L. cv Italica) heads. Food 645 Chemistry, 112, 646-653.

646 Van Loey, A., Ooms, V., Weemaes, C., Van den Broeck, I., Ludikhuyze, L., Indrawati, 647 Denys, S., \& Hendrickx, M. E. (1998). Thermal and pressure-temperature degradation 648 of chlorophyll in broccoli (Brassica oleracea L. italica) juice: A kinetic study. Journal 649 of Agricultural and Food Chemistry, 46, 5289-5294.

650 Vu, T. S., Smout, C., Sila, D. N., Loey, A. v., \& Hendrickx, M. E. (2006). The Effect of 651 Brine Ingredients on Carrot Texture during Thermal Processing in Relation to Pectin 
652 Depolymerization due to the $\beta$-Elimination Reaction. Journal of Food Science, 71, 653 E370-E375.

654 Wijngaard, H. H., Rossle, C., \& Brunton, N. (2009). A survey of Irish fruit and 655 vegetable waste and by-products as a source of polyphenolic antioxidants. Food 656 Chemistry, 116, 202-207. 
Figure 1. Compression force of non-treated and processed (blanching and high pressure processing) swede roots. Different letters indicate significant differences among treatments $(\mathrm{p}<0.001)$.

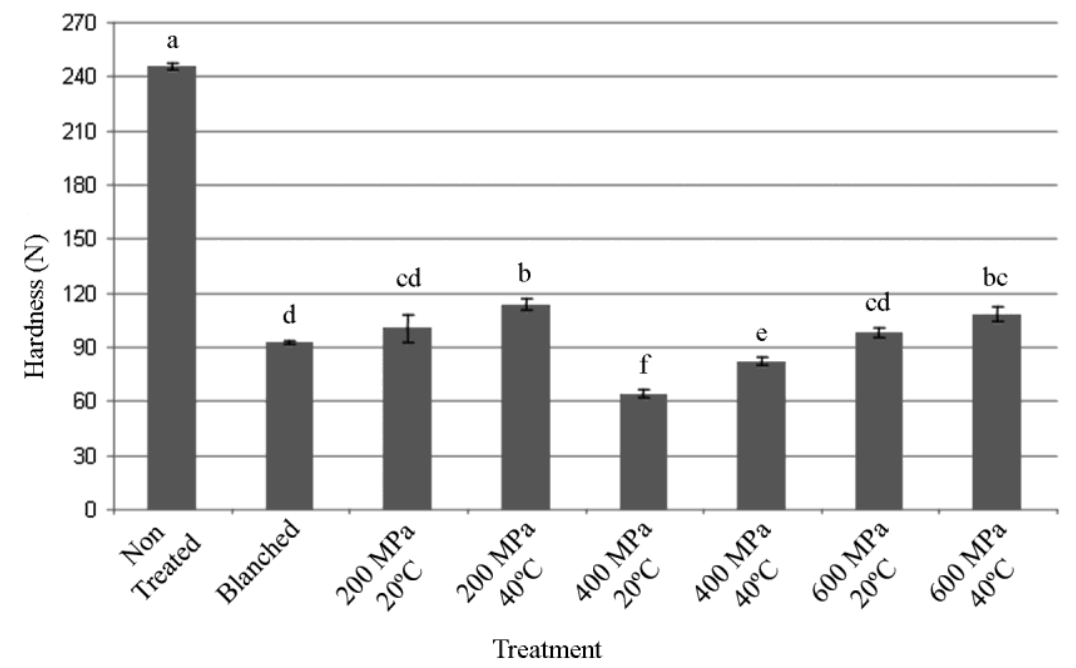


Figure 2. Cutting force and displacement at maximum cutting force of non-treated and processed (blanching and high pressure processing) swede roots. Bars with different letters indicate significant differences on cutting force among treatments $(\mathrm{p}<0.001)$. Upper points with different letters indicate significant differences on displacement values among treatments $(\mathrm{p}<0.01)$.

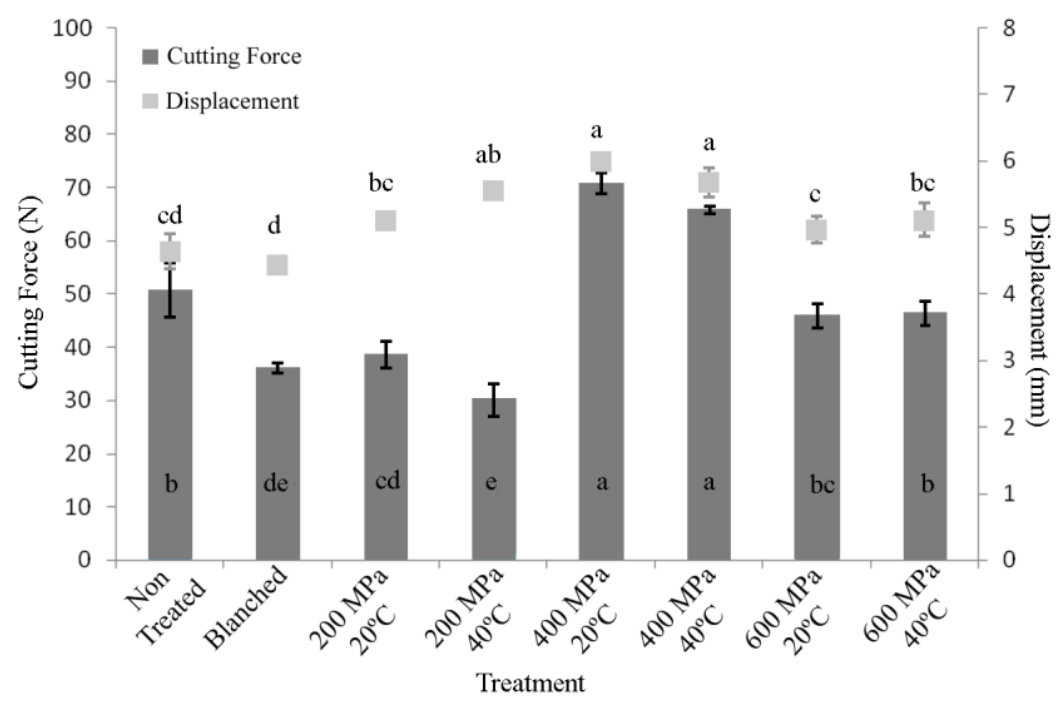


Figure 3: Expressible moisture of non-treated and processed (blanching and high pressure processing) swede roots. Bars with different letters are significantly different $(\mathrm{p}<0.001)$.

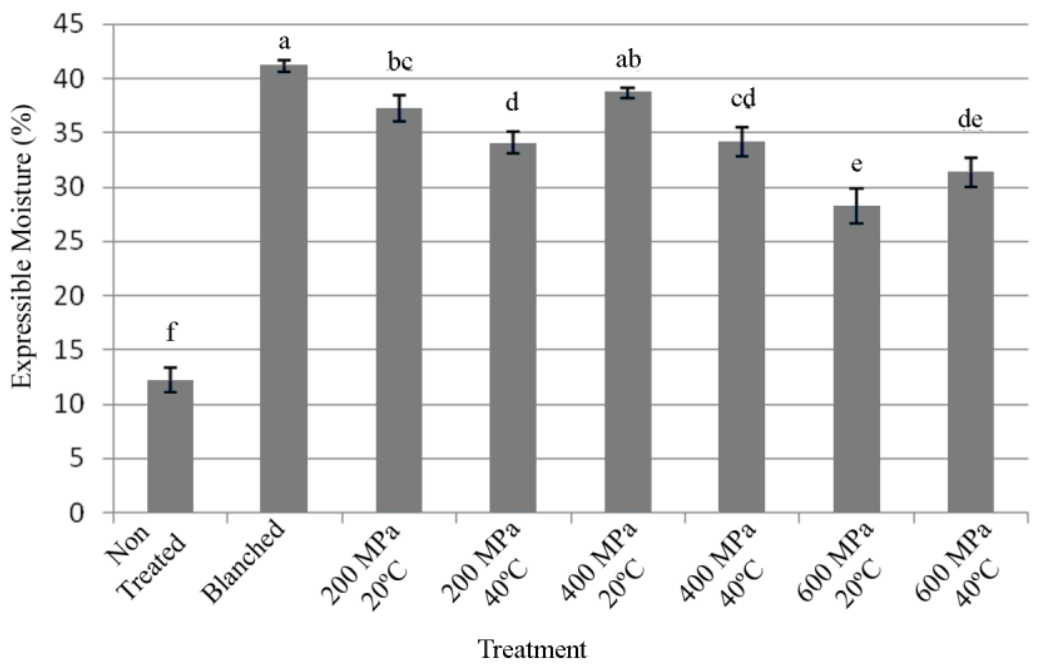


Table 1.

Instrumental colour parameters of non-treated and processed (blanching and high pressure processing) swede roots.

\begin{tabular}{|c|c|c|c|c|c|c|c|c|c|c|}
\hline & \multirow{2}{*}{$\begin{array}{l}\text { Non- } \\
\text { treated }\end{array}$} & \multirow{2}{*}{ Blanching } & \multicolumn{2}{|c|}{$200 \mathrm{MPa}$} & \multicolumn{2}{|c|}{$400 \mathrm{MPa}$} & \multicolumn{2}{|c|}{$600 \mathrm{MPa}$} & \multirow{2}{*}{$\mathrm{SE}^{1)}$} & \multirow{2}{*}{$\mathrm{p}^{2)}$} \\
\hline & & & $20^{\circ} \mathrm{C}$ & $40^{\circ} \mathrm{C}$ & $20^{\circ} \mathrm{C}$ & $40^{\circ} \mathrm{C}$ & $20^{\circ} \mathrm{C}$ & $40^{\circ} \mathrm{C}$ & & \\
\hline $\mathrm{L}^{*}$ & $66.59^{\mathrm{a}}$ & $44.96^{\mathrm{b}}$ & $26.32^{\mathrm{de}}$ & $25.86^{\mathrm{e}}$ & $28.77^{\mathrm{cd}}$ & $27.72^{\text {cde }}$ & $29.51^{\mathrm{c}}$ & $26.50^{\mathrm{de}}$ & 0.52 & $<0.001$ \\
\hline$a^{*}$ & $3.86^{\mathrm{a}}$ & $2.74^{\mathrm{ab}}$ & $3.40^{\mathrm{ab}}$ & $2.73^{\mathrm{ab}}$ & $1.88^{\mathrm{b}}$ & $2.04^{\mathrm{b}}$ & $2.18^{\mathrm{ab}}$ & $2.34^{\mathrm{ab}}$ & 0.31 & $<0.01$ \\
\hline$b^{*}$ & $16.81^{\mathrm{a}}$ & $16.75^{\mathrm{a}}$ & $10.71^{\mathrm{b}}$ & $9.66^{\mathrm{b}}$ & $11.32^{\mathrm{b}}$ & $11.32^{\mathrm{b}}$ & $12.02^{\mathrm{b}}$ & $10.68^{c}$ & 0.64 & $<0.001$ \\
\hline$\Delta \mathrm{E}$ & - & $21.72^{\mathrm{d}}$ & $40.74^{\mathrm{ab}}$ & $41.37^{\mathrm{a}}$ & $38.29^{b c}$ & $39.30^{\mathrm{abc}}$ & $37.44^{\mathrm{c}}$ & $40.59^{\mathrm{ab}}$ & 0.53 & $<0.001$ \\
\hline
\end{tabular}

Values are Least-square means (LS Means) of three replicates. Different letters within a row indicate significant differences among values.

${ }^{1)}$ Standard error.

${ }^{2)}$ Significance. 
Table 2.

Effect of the pressure level on quality parameters of pressurised swede roots

\begin{tabular}{lccccc}
\hline & $200 \mathrm{MPa}$ & $400 \mathrm{MPa}$ & $600 \mathrm{MPa}$ & $\mathrm{SE}^{1)}$ & $\mathrm{p}^{2)}$ \\
\hline $\mathrm{L}^{*}$ & $26.09^{\mathrm{b}}$ & $28.25^{\mathrm{a}}$ & $28.00^{\mathrm{a}}$ & 0.34 & $<0.01$ \\
$\mathrm{a}^{*}$ & $3.07^{\mathrm{a}}$ & $1.96^{\mathrm{b}}$ & $2.26^{\mathrm{b}}$ & 0.20 & $<0.01$ \\
$\Delta E$ & $41.06^{\mathrm{a}}$ & $38.79^{\mathrm{b}}$ & $39.01^{\mathrm{b}}$ & 0.38 & $<0.01$ \\
Total phenols $^{3)}$ & $349,4^{\mathrm{b}}$ & $353,6^{\mathrm{b}}$ & $399,3^{\mathrm{a}}$ & 11,2 & $<0.05$ \\
TEAC $^{4)}$ & $78.8^{\mathrm{b}}$ & $55.1^{\mathrm{c}}$ & $143.6^{\mathrm{a}}$ & 5.4 & $<0.001$ \\
\hline Results are Least-square means (LS Means) of six replicates. Different letters within a row indicate significant
\end{tabular}

Results are Least-square means (LS Means) of six replicates. Different letters within a row indicate significant differences among values.

${ }^{1)}$ Standard error.

2) Significance.

${ }^{3)}$ Expressed as mg gallic acid equivalent/100 g dry weight sample.

${ }^{4)}$ Expressed as trolox equivalent antioxidant capacity and measured as (IC50 Trolox $/ \mathrm{IC} 50_{\mathrm{s}}$ ) x $10^{5}$. 
Table 3.

Antioxidant indices and glucosinolate content of non-treated and processed (blanching and high pressure processing) swede roots.

\begin{tabular}{|c|c|c|c|c|c|c|c|c|c|c|}
\hline & \multirow{2}{*}{ Non-treated } & \multirow{2}{*}{ Blanching } & \multicolumn{2}{|c|}{$200 \mathrm{MPa}$} & \multicolumn{2}{|c|}{$400 \mathrm{MPa}$} & \multicolumn{2}{|c|}{$600 \mathrm{MPa}$} & \multirow{2}{*}{$\mathrm{SE}^{1)}$} & \multirow{2}{*}{$\mathrm{p}^{2)}$} \\
\hline & & & $20^{\circ} \mathrm{C}$ & $40^{\circ} \mathrm{C}$ & $20{ }^{\circ} \mathrm{C}$ & $40^{\circ} \mathrm{C}$ & $20^{\circ} \mathrm{C}$ & $40^{\circ} \mathrm{C}$ & & \\
\hline Ascorbic acid ${ }^{3)}$ & $846.72^{\mathrm{a}}$ & $685.29^{\mathrm{b}}$ & $526.68^{\mathrm{c}}$ & $529.62^{c}$ & $257.49^{\mathrm{d}}$ & $314.93^{\mathrm{d}}$ & $664.60^{\mathrm{bc}}$ & $568.15^{\mathrm{bc}}$ & 31.63 & $<0.001$ \\
\hline Total Phenols ${ }^{4)}$ & $436.25^{\mathrm{a}}$ & $367.68^{\mathrm{cd}}$ & $384.89^{\mathrm{bcd}}$ & $325.99^{\mathrm{e}}$ & $319.02^{\mathrm{e}}$ & $347.63^{\mathrm{de}}$ & $419.96^{\mathrm{ab}}$ & $387.82^{\mathrm{bc}}$ & 7.69 & $<0.001$ \\
\hline TEAC $^{5)}$ & $215.18^{\mathrm{a}}$ & $157.03^{\mathrm{b}}$ & $76.30^{\mathrm{cd}}$ & $81.20^{\mathrm{cd}}$ & $51.76^{\mathrm{d}}$ & $58.45^{\mathrm{d}}$ & $182.91^{\mathrm{ab}}$ & $104.27^{\mathrm{c}}$ & 7.37 & $<0.001$ \\
\hline Glucoraphanin $^{3)}$ & $0.46^{\mathrm{ab}}$ & $0.43^{\mathrm{b}}$ & $0.50^{\mathrm{ab}}$ & $0.43^{\mathrm{b}}$ & $0.64^{\mathrm{a}}$ & $0.54^{\mathrm{ab}}$ & $0.58^{\mathrm{ab}}$ & $0.54^{\mathrm{ab}}$ & 0.04 & $<0.05$ \\
\hline Progoitrin ${ }^{3)}$ & $0.33^{\mathrm{d}}$ & $0.37^{\mathrm{cd}}$ & $0.31^{\mathrm{d}}$ & $0.36^{\mathrm{d}}$ & $0.63^{\mathrm{a}}$ & $0.48^{\mathrm{bc}}$ & $0.53^{\mathrm{ab}}$ & $0.52^{\mathrm{b}}$ & 0.02 & $<0.001$ \\
\hline Glucobrassicanapin ${ }^{3)}$ & $1.04^{\mathrm{a}}$ & $0.72^{\mathrm{b}}$ & $0.52^{\mathrm{bc}}$ & $0.56^{\mathrm{bc}}$ & $0.62^{\mathrm{bc}}$ & $0.42^{\mathrm{c}}$ & $0.53^{\mathrm{bc}}$ & $0.51^{\mathrm{bc}}$ & 0.05 & $<0.001$ \\
\hline Glucobrassicin $^{3)}$ & $0.68^{\mathrm{a}}$ & $0.55^{\mathrm{b}}$ & $0.41^{\mathrm{c}}$ & $0.36^{\mathrm{cd}}$ & $0.28^{\mathrm{d}}$ & $0.38^{\mathrm{cd}}$ & $0.39^{\mathrm{c}}$ & $0.36^{\mathrm{cd}}$ & 0.02 & $<0.001$ \\
\hline
\end{tabular}

Values are Least-square means (LS Means) of three replicates. Different letters within a row indicate significant differences among values.

${ }^{1)}$ Standard error.

${ }^{2)}$ Significance.

${ }^{3)}$ Expressed as $\mathrm{mg} / \mathrm{g}$ dry weight sample.

4) Expressed as mg gallic acid equivalent/100 g dry weight sample.

5) Expressed as trolox equivalent antioxidant capacity and measured as (IC50 Trolox $\left./ \mathrm{IC} 50_{\mathrm{s}}\right) \times 10^{5}$ 